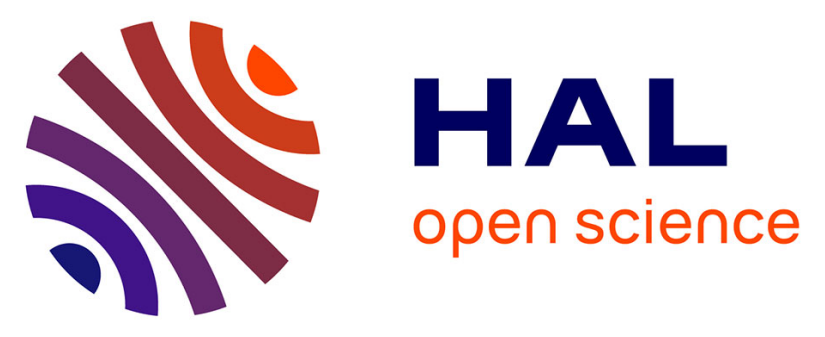

\title{
Nitrite Reduction by Trinuclear Copper Pyrazolate Complexes: An Example of a Catalytic, Synthetic Polynuclear NO Releasing System
}

Kaige Shi, Logesh Mathivathanan, Athanassios Boudalis, Philippe Turek, Indranil Chakraborty, Raphael G. Raptis

\section{To cite this version:}

Kaige Shi, Logesh Mathivathanan, Athanassios Boudalis, Philippe Turek, Indranil Chakraborty, et al.. Nitrite Reduction by Trinuclear Copper Pyrazolate Complexes: An Example of a Catalytic, Synthetic Polynuclear NO Releasing System. Inorganic Chemistry, 2019, 58 (11), pp.7537-7544. 10.1021/acs.inorgchem.9b00748 . hal-02298561

\section{HAL Id: hal-02298561 \\ https://hal.science/hal-02298561}

Submitted on 26 Sep 2019

HAL is a multi-disciplinary open access archive for the deposit and dissemination of scientific research documents, whether they are published or not. The documents may come from teaching and research institutions in France or abroad, or from public or private research centers.
L'archive ouverte pluridisciplinaire HAL, est destinée au dépôt et à la diffusion de documents scientifiques de niveau recherche, publiés ou non, émanant des établissements d'enseignement et de recherche français ou étrangers, des laboratoires publics ou privés. 


\title{
Nitrite Reduction by Trinuclear Copper Pyrazolate
}

\section{Complexes: An Example of a Catalytic, Synthetic Polynuclear NO Releasing System.}

Kaige Shi ${ }^{\#, a}$ Logesh Mathivathanan ${ }^{\#, a}$ Athanassios K. Boudalis, ${ }^{b}$ Philippe Turek, ${ }^{b}$ Indranil Chakraborty ${ }^{a}$ and Raphael G. Raptis ${ }^{* a}$

${ }^{a}$ Department of Chemistry and Biochemistry and Biomolecular Sciences Institute Florida International University, $11200 \mathrm{SW} 8^{\text {th }}$ Street, Miami, FL, 33199, USA.

${ }^{\mathrm{b}}$ Institut de Chimie UMR 7177 / Université de Strasbourg 4, rue Blaise Pascal / CS 90032 F-67081 STRASBOURG CEDEX, France

\begin{abstract}
Two trinuclear $\mathrm{Cu}^{\mathrm{II}}$ pyrazolato complexes with a $\mathrm{Cu}_{3}\left(\mu_{3}-\mathrm{E}\right)$-core $\left(\mathrm{E}=\mathrm{O}^{2-}\right.$ or $\left.\mathrm{OH}^{-}\right)$and terminal nitrite ligands in two coordination modes were characterized crystallographically, spectroscopically and electrochemically. One-electron oxidation of the $\mu_{3}-\mathrm{O}$ species produces a delocalized, mixed-valent, formally $\mathrm{Cu}_{2}{ }_{2} \mathrm{Cu}^{\mathrm{III}}$-nitrite, but no nitrate. In contrast, under reducing conditions -- addition of $\mathrm{PhSH}$ as an electron and proton donor -- both complexes mediate the reduction of nitrite, releasing NO.
\end{abstract}

\section{Introduction}


Nitrite is an important player of the biogeochemical nitrogen cycle, being reduced biologically to nitric oxide by $\mathrm{Cu}-, \mathrm{Fe}-$, or Mo-containing enzymes,${ }^{1}$ and oxidized to nitrate by Mo-containing ones, while analogous processes are also involved in the abiotic $\mathrm{N}_{2}$ cycle. ${ }^{2}$ Copper-containing nitrite reductase enzymes (CuNIR) comprise type-I and -II copper centers, with electrons shuttled from the type-I site to the catalytic, nitrito-binding type-II site. ${ }^{1,3}$ Nitrite is toxic to humans, requiring removal from drinking water when present, ${ }^{4}$ but also functions as a nitric oxide store in the blood, releasing NO under cell hypoxic conditions with numerous physiological responses. ${ }^{5}$ The photolysis of nitrous acid to $\mathrm{NO}$ and $\mathrm{OH}$-radicals is the main source of the latter in the atmosphere. ${ }^{6}$ Synthetic transition metal nitrite compounds, especially those of $\mathrm{Fe}$ and $\mathrm{Cu}$, are of interest in relation to the mechanism of the activity of nitrite reductase enzymes. ${ }^{7,8}$ However, as a ligand, nitrite has not been studied in as much detail as its fully oxidized nitrate congener (a CCDC search on 26/4/2019 gave 2106 entries for $\mathrm{Cu}-\mathrm{ONO}_{2}$, but only 141 for $\mathrm{Cu}-\mathrm{ONO}$ and 34 for $\mathrm{Cu}-\mathrm{NO}_{2}$ (Cambridge Structural Database version 5.0, update Feb. 2019)), possibly because of its instability - nitrite is often either oxidized to nitrate or reduced to $\mathrm{NO}$, even under mild conditions. Neither has the function of a $\mathrm{Cu}^{\mathrm{I} / \mathrm{II}}-\mathrm{NO}_{2}$ center in CuNIR been fully understood; while multiple model studies have pointed to redox-induced release of $\mathrm{N}_{2} \mathrm{O}$ and $\mathrm{NO}$ from the $\mathrm{Cu}^{\mathrm{I} / I I}$ centers of CuNIR, the order of events (i.e., nitritecentered, or metal-centered reduction occurs first) has not been fully elucidated. ${ }^{9}$ Whereas several synthetic $\mathrm{Fe}^{\mathrm{II}} / \mathrm{Cu}^{\mathrm{I}}$ nitrito complexes have been shown to release NO, and many $\mathrm{Cu}^{\mathrm{II}}$ nitrito complexes have been reported, only a handful of synthetic $\mathrm{Cu}^{\mathrm{II}}$ and $\mathrm{Fe}^{\mathrm{II}} \mathrm{NO}$-releasing complexes are known, to date. ${ }^{3,10-13}$ To our knowledge, there is no example of a polynuclear complex with more than one nitrite ligand in the literature. In contrast, examples of mononuclear $\mathrm{Cu}^{\text {II }}$ complexes with two or three nitrito ligands in various coordination modes are known. ${ }^{14,15}$ 
In earlier work, we have shown that trinuclear copper(II) complexes of the formula $\left[\mathrm{Cu}_{3}\left(\mu_{3^{-}}\right.\right.$ $\left.\mathrm{O})(\mu-4-\mathrm{R}-\mathrm{pz})_{3} \mathrm{X}_{3}\right]^{\mathrm{z}}-\mathrm{pz}^{-}=$pyrazolato anion; $\mathrm{R}=\mathrm{H}, \mathrm{CH}(\mathrm{O}), \mathrm{Cl}, \mathrm{Br}$ and $\mathrm{ONO} ; \mathrm{X}^{-}=\mathrm{Cl}^{-}, \mathrm{NCS}^{-}$, $\mathrm{CH}_{3} \mathrm{COO}^{-}, \mathrm{CF}_{3} \mathrm{COO}^{-}$and pyridine; $\mathrm{z}=$ charge - can be oxidized to the corresponding $z+1$, formally $\mathrm{Cu}_{2}{ }_{2}^{\mathrm{II}} \mathrm{Cu}^{\mathrm{III}}$, species. ${ }^{16,17}$ In one case, the mixed-valent $\mathrm{R}=\mathrm{H}$ and $\mathrm{X}^{-}=\mathrm{PhCOO}^{-}$complex was crystallographically characterized. ${ }^{18}$ The $\mathrm{E}_{1 / 2}$-values for the aforementioned oxidation follow the expected trend for the various terminal X-ligands: the higher $\mathrm{X}$ is in the spectrochemical series, ${ }^{19,20}$ the easier the oxidation. Following-up on this observation, we show here that when $\mathrm{X}^{-}$ $=\mathrm{ONO}^{-}$the one-electron oxidation of the all- $\mathrm{Cu}^{\mathrm{II}}$ complex $\left[\mathrm{Cu}_{3}\left(\mu_{3}-\mathrm{O}\right)(\mu-\mathrm{pz})_{3}(\mathrm{ONO})_{3}\right]^{2-}, \mathbf{1}$, is achieved at even more cathodic redox potential, resulting in the in situ spectroscopicallycharacterized $\left[\mathrm{Cu}_{3}\left(\mu_{3}-\mathrm{O}\right)(\mu-\mathrm{pz})_{3}(\mathrm{ONO})_{3}\right]^{-}$, the easiest accessible $\mathrm{Cu}_{2}{ }_{2} \mathrm{Cu}^{\mathrm{III}}$ species known to date. We also present a new pyrazolato complex, with 4-phenylpyrazolato bridging ligands, $(\mathrm{PPN})\left[\mathrm{Cu}_{3}\left(\mu_{3}-\mathrm{OH}\right)(\mu-4-\mathrm{Ph}-\mathrm{pz})_{3}(\mathrm{ONO})_{3}\right](3)$. Compound 3 is redox-inert, becoming redox-active upon in situ deprotonation by addition of a base during electrochemistry experiments. Most importantly, we present here an initial report of the catalytic NO-release mediated by compounds $\mathbf{1}$ and $\mathbf{3}$ upon stoichiometric addition of $\mathrm{PhSH}$ as an one-eletron donor.

\section{Experimental Section}

Materials and Methods

All reagents were purchased from commercial sources and used as received. Solvents were purified using standard techniques. ${ }^{21}[\mathrm{PPN}]_{2}\left[\mathrm{Cu}_{3}\left(\mu_{3}-\mathrm{Cl}\right)_{2}(\mu-\mathrm{pz})_{3} \mathrm{Cl}_{3}\right]$ was prepared according to a literature procedure. ${ }^{16}$ Elemental analyses $(\mathrm{C}, \mathrm{H}, \mathrm{N})$ were performed by Galbraith Laboratories, Inc., Knoxville, Tennessee. IR spectra were recorded on a Spectrum One Perkin-Elmer FT-IR Spectrophotometer (ATR mode) in the 4000-600 $\mathrm{cm}^{-1}$ region. Electrochemical measurements were performed under Ar atmosphere at ambient temperature in a BAS-Epsilon electrochemical 
measurement system using a three-electrode system (glassy carbon working, Pt-wire auxiliary and $\mathrm{Ag} / \mathrm{AgNO}_{3}$ reference electrodes), using $0.1 \mathrm{M} \mathrm{TBAPF} / \mathrm{CH}_{2} \mathrm{Cl}_{2}$ as the supporting electrolyte. Ferrocene was used as the internal standard. Potentials are reported $v s . \mathrm{Fc}^{+} / \mathrm{Fc}$.

Single crystal X-ray diffraction data were collected on a Bruker D8 QUEST CMOS system equipped with a TRIUMPH curved-crystal monochromator and a Mo-Ka fine-focus X-ray tube with graphite monochromated Mo-K $\alpha$ radiation $(\lambda=0.71073 \AA)$ at ambient or low temperature using the APEX3 or APEX2 suite. ${ }^{22}$ Frames were integrated with the Bruker SAINT software package using a narrow-frame algorithm. Absorption effects were corrected using the multi-scan method (SADABS). ${ }^{23}$ Structures were solved by intrinsic phasing methods with ShelXT ${ }^{24}$ and refined with ShelXL using full-matrix least-squares minimization Using Olex2. ${ }^{25}$ All nonhydrogen atoms were refined anisotropically. Hydrogen atoms positions were calculated and fixed by HFIX with their thermal ellipsoids riding on those of their carbon atoms.

EPR spectra of 1 were recorded on a Bruker ESP300 spectrometer using a Bruker 4102ST rectangular cavity operating in the TE102 mode. For variable-temperature experiments the cavity was fitted in an ESR900 dynamic continuous flow cryostat and the temperature was regulated with an Oxford ITC4 Intelligent Temperature Controller. EPR spectra of $\mathbf{3}$ were collected on a Bruker EMXplus spectrometer fitted with an EMX microX bridge and a Bruker ER4122SHQE cavity operating in the TE011 mode. For low temperature experiments, the cavity was fitted with an ESR900 dynamic continuous flow cryostat controlled with an Oxford ITC503S Intelligent Temperature Controller. EPR solutions were prepared in dry $\mathrm{CH}_{2} \mathrm{Cl}_{2}$ freshly distilled over $\mathrm{CaH}_{2}$ and deoxygenated by freeze-thaw cycles and flame-sealed in the EPR tubes. 
Synthesis of $(\mathrm{PPN})_{2}\left[\mathrm{Cu}_{3}\left(\mu_{3}-\mathrm{O}\right)(\mu-\mathrm{pz})_{3}(\mathrm{ONO})_{3}\right](\mathbf{1})$

To a $4 \mathrm{~mL} \mathrm{CH}_{2} \mathrm{Cl}_{2}$ solution of $(\mathrm{PPN})_{2}\left[\mathrm{Cu}_{3}\left(\mu_{3}-\mathrm{Cl}\right)_{2}(\mu-\mathrm{pz})_{3} \mathrm{Cl}_{3}\right](100 \mathrm{mg}, 0.058 \mathrm{mmol})$ was added a solution of $\mathrm{NaNO}_{2}(20.3 \mathrm{mg}, 0.029 \mathrm{mmol})$ in $0.5 \mathrm{~mL} \mathrm{H} 2 \mathrm{O}$ and $2 \mathrm{~mL} \mathrm{MeOH}$. The reaction mixture was stirred for $24 \mathrm{~h}$ at ambient temperature. After filtration and treatment of the filtrate with $10 \mathrm{~mL} \mathrm{Et}_{2} \mathrm{O}$, purple crystals of $\mathbf{1}$ were formed by slow evaporation at ambient temperature; Yield, 62\%. Anal. Calcd./Found for $\mathrm{C}_{81} \mathrm{H}_{69} \mathrm{~N}_{11} \mathrm{Cu}_{3} \mathrm{O}_{7} \mathrm{P}_{4}(\%) \mathrm{C}, 59.44 / 59.77 ; \mathrm{H}, 4.28 / 4.23$; N, 9.49/9.41. FTIR (cm-1): 1439 (m), 1377 (m), $v_{\text {as }}(\mathrm{ONO}) ; 1259(\mathrm{~s}), \mathrm{v}_{\mathrm{s}}(\mathrm{ONO}) ; 1114(\mathrm{~s}), 1052$ (m), 997 (w), 872 (w), $\delta(\mathrm{ONO}) ; 722$ (s), 689 (s). ${ }^{1} \mathrm{H}-\mathrm{NMR}\left(\mathrm{CDCl}_{3}, \mathrm{ppm}\right): 39.96\left(3 \mathrm{H}, \mathrm{w}_{1 / 2}=88 \mathrm{~Hz}\right)$; $37.21\left(6 \mathrm{H}, \mathrm{w}_{1 / 2}=145 \mathrm{~Hz}\right) . \mathrm{UV}$-vis $\left(\mathrm{CH}_{2} \mathrm{Cl}_{2}, \mathrm{~cm}^{-1}\right): 28111,36152,37087,38704$. UV-vis (THF, $\left.\mathrm{cm}^{-1}\right): 14537,29389,36328,37373,38407$.

Synthesis of $(\mathrm{PPN})\left[\mathrm{Cu}_{3}\left(\mu_{3}-\mathrm{OH}\right)(\mu-4-\mathrm{Ph}-\mathrm{pz})_{3} \mathrm{Cl}_{3}\right] \cdot \mathrm{CH}_{2} \mathrm{Cl}_{2}(\mathbf{2})$ A mixture of $\mathrm{CuCl}_{2} \cdot 2 \mathrm{H}_{2} \mathrm{O}(0.12 \mathrm{mmol}, 20.5 \mathrm{mg}), 4-\mathrm{Ph}-\mathrm{pzH}$ (0.12 mmol, $\left.17.3 \mathrm{mg}\right), \mathrm{NaOH}(0.16$ mmol, $6.4 \mathrm{mg})$, PPNCl (0.02 mmol, $11.8 \mathrm{mg})$ was stirred in $\mathrm{CH}_{2} \mathrm{Cl}_{2}(15 \mathrm{~mL})$ for $24 \mathrm{~h}$. After filtration, the product was recrystallized by slow $\mathrm{Et}_{2} \mathrm{O}$ vapor diffusion into the $\mathrm{CH}_{2} \mathrm{Cl}_{2}$ solution. Yield, 72\%. Anal. Calcd./Found for $\mathrm{C}_{64} \mathrm{H}_{54} \mathrm{Cl}_{5} \mathrm{Cu}_{3} \mathrm{~N}_{7} \mathrm{OP}_{2}$ : C, 56.39/56.34; H, 4.00/3.99; N, 7.19/7.21.

Synthesis of $(\mathrm{PPN})_{2}\left[\mathrm{Cu}_{3}\left(\mu_{3}-\mathrm{OH}\right)(\mu-4-\mathrm{Ph}-\mathrm{pz})_{3}(\mathrm{ONO})_{3}\right] \cdot\left(\mathrm{CH}_{2} \mathrm{Cl}_{2}\right)_{0.5}(\mathbf{3})$

To a $4 \mathrm{~mL} \mathrm{CH} \mathrm{Cl}_{2}$ solution of $2(0.071 \mathrm{mmol}, 100 \mathrm{mg})$ was added a solution of $\mathrm{NaNO}_{2}(0.35$ mmol, $24.6 \mathrm{mg}$ ) in $2 \mathrm{~mL} \mathrm{MeOH}$, and the reaction mixture was mixed at room temperature overnight. The mixture was filtered and X-ray quality crystals of $\mathbf{3}$ were obtained by treating the filtrate with $4 \mathrm{~mL}$ hexane. Well-shaped crystals of $\mathbf{3}$ suitable for X-ray diffraction were obtained after three days. Yield, 80\%. Anal. Calcd./Found for $\mathrm{C}_{127} \mathrm{H}_{108} \mathrm{Cl}_{2} \mathrm{Cu}_{6} \mathrm{~N}_{20} \mathrm{O}_{14} \mathrm{P}_{4}$ : C, 56.31/56.06; H, 3.95/4.02; N, 10.35/10.19. FTIR: $1436(\mathrm{w}), 1360(\mathrm{w}), v_{\mathrm{as}}(\mathrm{ONO}) ; 1215(\mathrm{~m}), v_{\mathrm{s}}(\mathrm{ONO}) ; 1114$ 
(s), $1056(\mathrm{~m})$, 952(w), 848(w), d (ONO); 758 (m), 722 (s), 684 (s). 1H-NMR (DMSO-d $\left.d^{6}, \mathrm{ppm}\right)$ :

$\left.38.32\left(6 \mathrm{H}, w_{1 / 2}=186 \mathrm{~Hz}\right), 15.89 \mathrm{~Hz}, 19.17 \mathrm{~Hz}, 17 \mathrm{~Hz}\right)$. UV-vis $\left(\mathrm{CH}_{2} \mathrm{Cl}_{2}, \mathrm{~cm}^{-1}\right): 26692,38469$;

UV-vis (THF, $\mathrm{cm}^{-1}$ ): 27528, 38154.

Qualitative detection of NO generated from $\mathbf{1}$ and $\mathbf{3}$ by addition of thiophenol:

Method A: A solution of $\mathbf{1}$ in $\mathrm{CH}_{2} \mathrm{Cl}_{2}(15 \mathrm{mg}, 0.092 \mathrm{mmol})$ or $\mathbf{3}(15 \mathrm{mg}, 0.006 \mathrm{mmol})$ was prepared in a small vial. This vial was placed inside a larger one containing a solution of CoTPP (6.2 $\mathrm{mg}, 0.009 \mathrm{mmol}$ ) in $2 \mathrm{~mL} \mathrm{CH}_{2} \mathrm{Cl}_{2}$ and the larger vial was capped with a septum. A solution of $\mathrm{PhSH}\left(2.88 \mu \mathrm{L}, 0.028 \mathrm{mmol} ; 1: 3\right.$ stoichiometry), in $2 \mathrm{~mL} \mathrm{CH}_{2} \mathrm{Cl}_{2}$ was carefully injected to the solution of $\mathbf{1}$ via a syringe. UV-vis spectrum of the CoTPP solution was recorded after $2 \mathrm{~h}$ and spectral changes were observed due to NO binding to CoTPP (Figures S3, S4). The experiment was repeated with varying equivalents of $\mathrm{PhSH}(1: 1,1: 2,1: 3,1: 4,1: 5$ and 1:6). A blank experiment was conducted with the larger vial containing CoTPP $(6.2 \mathrm{mg}, 0.009 \mathrm{mmol})$ in $2 \mathrm{~mL}$ $\mathrm{CH}_{2} \mathrm{Cl}_{2}$ and a smaller vial containing equimolar quantities of $\mathrm{NaNO}_{2}$ and $\mathrm{PhSH}$. No shift in the UV-vis absorption spectrum of CoTPP was observed after $2 \mathrm{~h}$ (Figure S5).

\section{Quantitative measurement of NO generated from 1 and 3 by addition of thiophenol.}

Release of NO was quantitatively determined as $\mathrm{NO}$ amperograms using the inNO-T nitric oxide monitoring system (Innovative Instruments, Inc). An AmiNO-100 sensor was dipped into an open vial containing $5 \times 10^{-5} \mathrm{M} \mathrm{CH}_{2} \mathrm{Cl}_{2}$ solutions of $\mathbf{1}$ or $\mathbf{3}$ under constant stirring. The released $\mathrm{NO}$ was measured in $\mathrm{pA} / \mathrm{nM}$ response curves, which were converted to $\mathrm{nM}$ of $\mathrm{NO}$ by calibration with standard $\mathrm{NaNO}_{2} / \mathrm{KI} / \mathrm{H}_{2} \mathrm{SO}_{4}$ solutions, according to the procedures described by the manufacturer. 


\section{Results}

Compound 1 was obtained from a metathetical reaction of the chloro-terminated complex ${ }^{16}$ $\left[\mathrm{Cu}_{3}\left(\mu_{3}-\mathrm{O}\right)(\mu-\mathrm{pz})_{3} \mathrm{Cl}_{3}\right]^{2-}$ with excess $\mathrm{NaNO}_{2}$ in $\mathrm{CH}_{2} \mathrm{Cl}_{2}$ and was recrystallized from $\mathrm{CH}_{2} \mathrm{Cl}_{2} / \mathrm{Et}_{2} \mathrm{O}$ at ambient temperature, resulting in purple $\mathrm{X}$-ray quality crystals of $(\mathrm{PPN})_{2}\left[\mathrm{Cu}_{3}\left(\mu_{3}-\mathrm{O}\right)(\mu-\mathrm{pz})_{3}(\mathrm{ONO})_{3}\right], \mathbf{1}$ (monoclinic, $P 2_{1} / \mathrm{c}$ space group). It consists of a ninemembered $[\mathrm{Cu}-\mathrm{N}-\mathrm{N}]_{3}$ metallacycle in which the $\mathrm{Cu}$-atoms are held together by trans pyrazolato bridges, accommodating an almost planar $\mathrm{Cu}_{3}\left(\mu_{3}-\mathrm{O}\right)$ core (Figure 1). Complex 1 contains two $\kappa^{1}-\mathrm{O}$ and one $\kappa^{2}-\mathrm{O}, \mathrm{O}$ nitrite ligands, with a $C_{2}$ axis going through the nitrogen of the $\kappa^{2}-\mathrm{ONO}$ ligand, $\mathrm{Cu}$ - and $\mu_{3}-\mathrm{O}$-atoms.

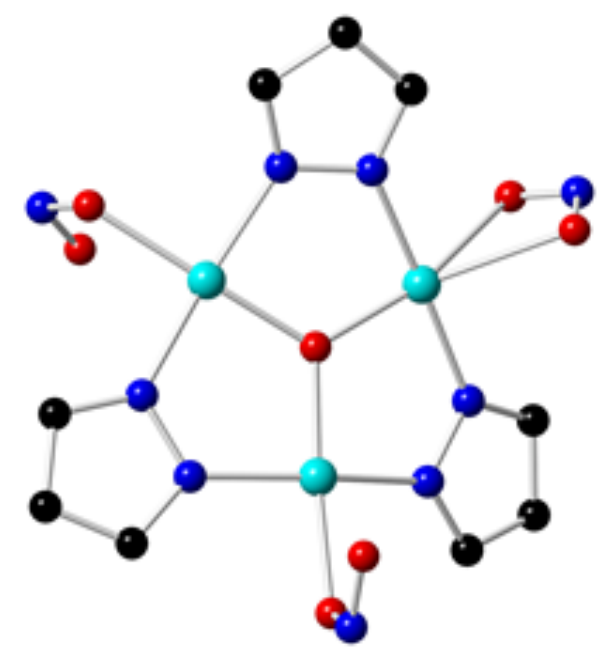

Figure 1. Ball-and-stick representation of 1. Color coding: Cyan, $\mathrm{Cu}$; blue, N; red, O; black, C. H-atoms and PPN counter ions not shown for clarity. Selected interatomic distances $(\AA)$ and angles $\left({ }^{\circ}\right)$ : $\mathrm{Cu} \cdots \mathrm{Cu}: 3.248(5), 3.261(7) ; \mathrm{Cu}-\left(\mu_{3}-\mathrm{O}\right)$ : 1.874(2), 1.880(1); $\mathrm{Cu}-\mathrm{N}: 1.947(2)$ 1.959(2); Cu-O(NO): 2.349(3), 2.015(2), 2.653(4); Cu-O-Cu: 119.85(5), 120.30(1).

The $\mathrm{Cu}-\mathrm{O}$ distances involving the $\kappa^{2}$-nitrite, $2.349(3) \AA$, are intermediate to those of the bonded $(2.015(2) \AA)$ and non-bonded (2.653(4) $\AA$ ) $\mathrm{Cu}-\mathrm{O}$ distances to the $\kappa^{1}-\mathrm{O}$ nitrite. The latter 
are respectively shorter and longer than the 2.059(3) and 2.483(4) $\AA$ distances in a related threefold symmetric nitrate complex containing $\kappa^{1}-\mathrm{ONO}_{2}$ ligands. ${ }^{26}$ Within the $\kappa^{1}-\mathrm{O}$ nitrites, the $\mathrm{Cu}$ coordinated $\mathrm{O}$-atom has its $\mathrm{N}-\mathrm{O}$ bond elongated compared to that of the dangling O-atom in both 1 and 3. However, the $\kappa^{2}-\mathrm{O}, \mathrm{O}$ nitrite has the shortest (not activated) $\mathrm{N}-\mathrm{O}$ bond lengths. This is consistent with the proposal that nitrite ions coordinate unsymmetrically to the $\mathrm{Cu}^{2+}$ centers at the catalytic site of CuNIR enzymes. ${ }^{27-29}$ The O-N-O angles for both $\kappa^{1}-\mathrm{O}$ and $\kappa^{2}-\mathrm{O}, \mathrm{O}$ nitrites, $114.5^{\circ}-117.1^{\circ}$, fall within the range of CuNIR-model complexes (Scheme 1). ${ }^{15}$ The dihedral angle between the $\mathrm{ONO}$ and $\mathrm{OCuO}$ planes are $0.98(7)^{\circ}$ and $0.0^{\circ}$ for the $\kappa^{1}-\mathrm{O}$ and $\kappa^{2}-\mathrm{O}, \mathrm{O}$ nitrites of $\mathbf{1}$, respectively, different than the $2^{\circ}$ to $75^{\circ}$ values reported for CuNIR. ${ }^{15}$
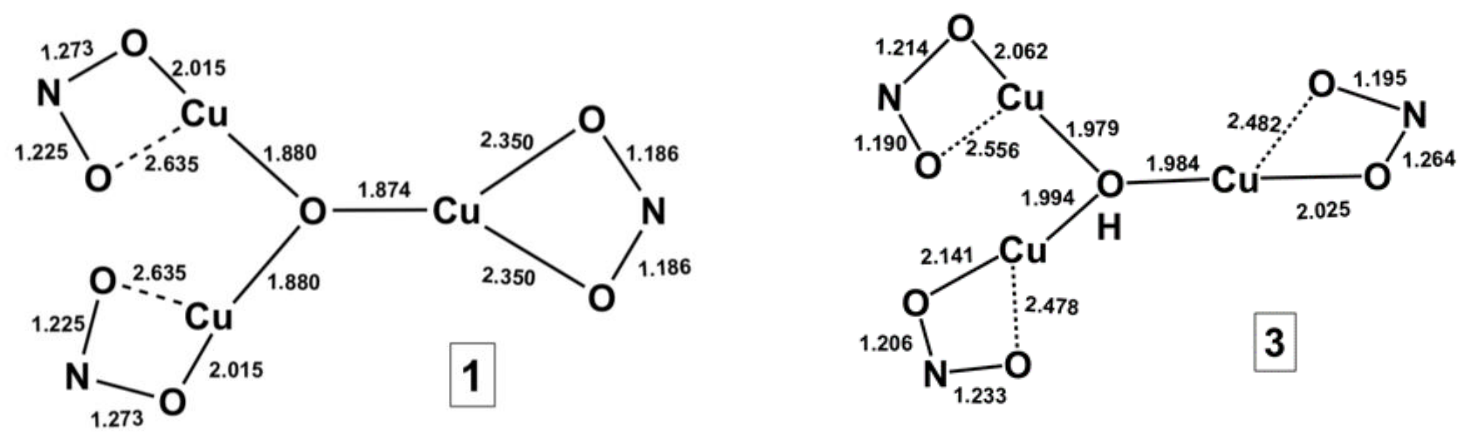

Scheme 1. Interatomic distances $(\AA)$ for $\mathrm{Cu}_{3}\left(\mu_{3}-\mathrm{O}\right)$ and $\mathrm{Cu}_{3}\left(\mu_{3}-\mathrm{OH}\right)$ cores for $\mathbf{1}$ and $\mathbf{3}$.

Compound $\mathbf{3}$ was prepared from its corresponding $\mathrm{Cl}$-terminated compound, $\mathbf{2}$, using a similar method as described above for $\mathbf{1}$; adding an excess of $\mathrm{NaNO}_{2}$ in $\mathrm{MeOH}$ to a solution of $\mathbf{2}$ in $\mathrm{CH}_{2} \mathrm{Cl}_{2}$ produced 3 in a high yield and $\mathrm{X}$-ray quality crystals were grown by slow diffusion of $\mathrm{Et}_{2} \mathrm{O}$ vapors into its $\mathrm{CH}_{2} \mathrm{Cl}_{2}$ solution. Whereas 2 crystallizes in monoclinic $P 2_{1} / n$ (Table S1, Fig. S2), compound 3 crystallizes in the triclinic $P \overline{1}$ space group with a whole molecule in the asymmetric unit. Three nitrite ligands are $\kappa^{1}$-O-coordinated to $\mathrm{Cu}$-centers with $\mathrm{Cu}-\mathrm{O}_{\mathrm{ONO}}$ bonding 
distances of 2.026(3), 2.141(4) and 2.062(4) $\AA$ and non-bonded $\mathrm{Cu}^{\cdots} \mathrm{O}$ distances of 2.481(5), 2.476(4) and 2.553(5) $\AA$. Of the three nitrito ligands, one is $s y n$ to the $\mu_{3}-\mathrm{OH}$ group while the other two are anti. The $\mu_{3}-\mathrm{OH}$ groups from adjacent $\mathrm{Cu}_{3}$-units form strong $\mathrm{H}$-bonds with the bound $\mathrm{O}$ of the nitrito ligand $\left[\mathrm{O}(\mathrm{H})^{\cdots} \mathrm{O} \mathrm{O}: 2.771(7) \AA\right]$ (Figure 2). A similar H-bonded dimer-oftrimers mediating magnetic interactions between the two $\mathrm{Cu}_{3}$ units was recently reported by us. ${ }^{30}$ The $\mathrm{Cu}-\left(\mu_{3}-\mathrm{OH}\right)$ distances of $\mathbf{3}$ are longer than the $\mathrm{Cu}-\left(\mu_{3}-\mathrm{O}\right)$ of $\mathbf{1}$, as expected, but rather short compared to other $\mathrm{Cu}_{3}-\left(\mu_{3}-\mathrm{OH}\right)$ complexes reported in the literature by us and others. ${ }^{16,31,32}$ In the infrared spectrum of compound 1 (Figure S6), the asymmetric nitrite stretches, $v_{\text {as }}(\mathrm{N}-\mathrm{O})$, are identified with strong bands at $1439 \mathrm{~cm}^{-1}$ and $1377 \mathrm{~cm}^{-1}$, whereas the symmetric $v_{\text {sym }}(\mathrm{N}-\mathrm{O})$ is assigned to a band at $1259 \mathrm{~cm}^{-1}$, in agreement with those reported for other nitrito complexes in the literature. ${ }^{15,33}$ The corresponding bands for 3 appear at $1436 \mathrm{~cm}^{-1}, 1360 \mathrm{~cm}^{-1}$ and $1114 \mathrm{~cm}^{-1}$ (Figure S7). ${ }^{15} \mathrm{~N}$-labeling studies by others of an $\kappa^{2}$-ONO $\mathrm{Cu}^{\mathrm{II}}$-complex have revealed that the IR-active O-N-O bending vibration of nitrite, $\delta(\mathrm{ONO})$, occurs at $877 \mathrm{~cm}^{-1} \cdot{ }^{33}$ A similar weak band is observed at $872 \mathrm{~cm}^{-1}$ for $\mathbf{1}$ and $848 \mathrm{~cm}^{-1}$ for 3 . The $\kappa^{1}$ - and $\kappa^{2}$-ONO binding modes do not differ significantly in vibrational spectra, as has already been reported elsewhere. ${ }^{33}$
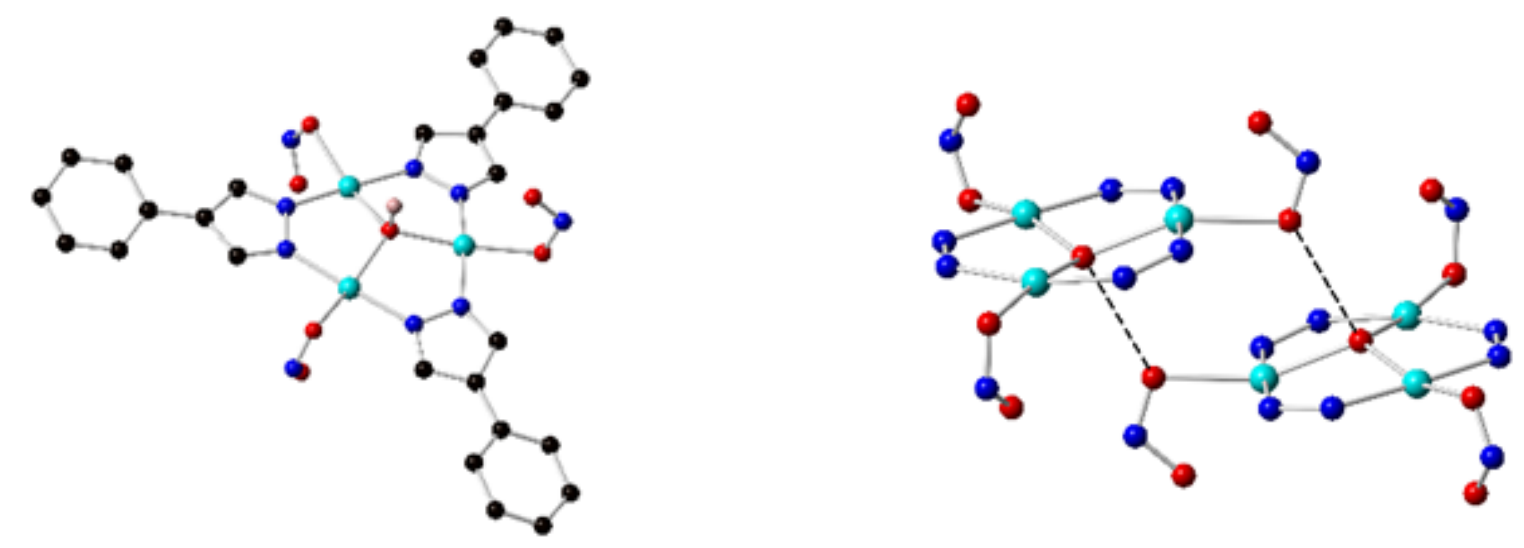

Figure 2. Molecular structure of $\mathbf{3}$ showing (left) the syn- and anti- conformations of ONO ligands; carbonic $\mathrm{H}$-atoms, $\mathrm{PPN}$ counter ion and $\mathrm{CH}_{2} \mathrm{Cl}_{2}$ are hidden for clarity; (right) $\mathrm{H}$-bonded 
(shown by dashed lines) dimeric structure of 3. Color coding: Cyan, $\mathrm{Cu}$; blue, $\mathrm{N}$; red, O; black, $\mathrm{C}$; pink, H. Selected interatomic distances $(\AA)$ and angles $\left({ }^{\circ}\right)$ : $\mathrm{Cu} \cdots \mathrm{Cu}: 3.350(5)-3.404(6) ; \mathrm{Cu}-$ $\left(\mu_{3}-\mathrm{OH}\right): 1.979(2)-1.993(2) ; \mathrm{Cu}-\mathrm{N}: 1.941(3)-1.930(3) ; \mathrm{Cu}-\mathrm{O}(\mathrm{NO}): 2.026(3), 2.062(4), 2.141(4)$; $\mathrm{Cu}-\mathrm{O}-\mathrm{Cu}: 115.19(1), 118.28(2)$.

To assess the stability of the complexes in solution, EPR spectra in frozen $\mathrm{CH}_{2} \mathrm{Cl}_{2}$ were recorded for $\mathbf{1}$ and $\mathbf{3}$ at $4.2 \mathrm{~K}$ (Figure 3). Both spectra exhibited similar characteristics typical of antiferromagnetically-coupled half-integer spin triangles experiencing antisymmetric exchange (or Dzyaloshinksii-Moriya) interactions, previously manifested in other complexes of this family. ${ }^{30,34}$ The spectra of $\mathbf{1}(\mathbf{3})$ consist of an absorption-like peak at $g=2.14(2.18)$ and a derivative feature at $g=1.87(1.84)$, with a broad trough centered at $g=1.73(1.74)$. The absorption-like peaks are attributed to the $g_{\|}$resonances and appear significantly broadened, due to unresolved, or partially resolved, hyperfine interactions. The derivative features are attributed to the $g_{\perp}$ resonances and they owe their low $g$-values to antisymmetric exchange interactions that induce a high anisotropy to the ground $S_{\mathrm{T}}=1 / 2$ state. $^{35,36}$ The broad profile of these features has been explained by the combination of distributions of the magnetic exchange interactions $(J$ strain) acting in tandem with the antisymmetric exchange interactions. ${ }^{37,38}$ The presence of these broad derivative features with $g<2$ is compelling evidence that the EPR spectra correspond to exchange-coupled systems with $S_{\mathrm{T}}=1 / 2$ ground states, and not paramagnetic $S=1 / 2$ mononuclear $\mathrm{Cu}^{\mathrm{II}}$ complexes. 


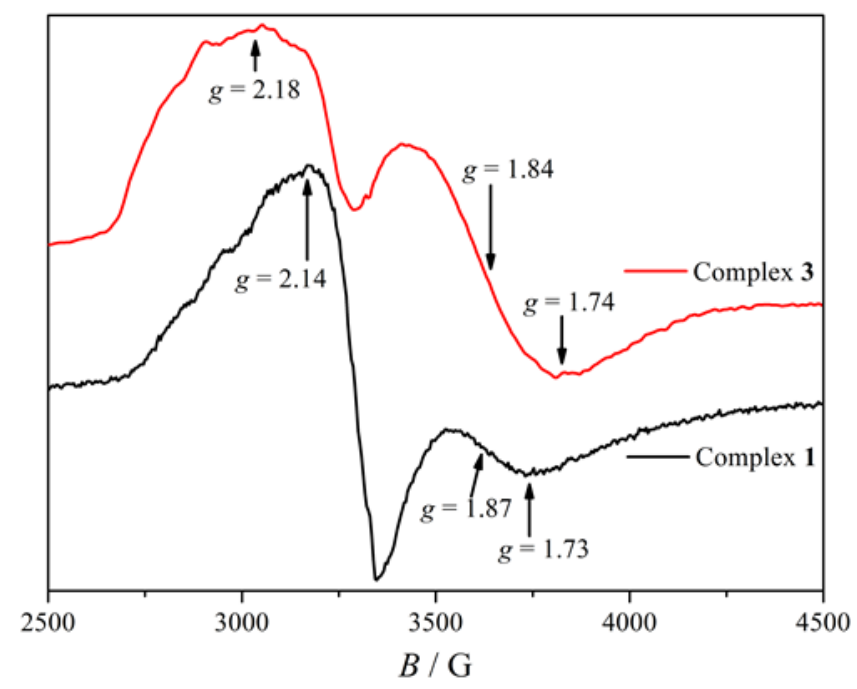

Figure 3. X-band EPR spectra of complexes 1 (black) and 3 (red) in frozen $\mathrm{CH}_{2} \mathrm{Cl}_{2}$ solutions $(4.2 \mathrm{~K})$. Experimental conditions for $\mathbf{1}: f=9.43 \mathrm{GHz}$, mod. ampl. $=2 \mathrm{G}_{\mathrm{pp}}$, micr. power $=2 \mathrm{~mW}$; for 3: $f=9.31 \mathrm{GHz}$, mod. ampl. $=5 \mathrm{G}_{\mathrm{pp}}$, micr. power $=2.44 \mathrm{~mW}$.

\section{Copper-based oxidation of 1 and 3.}

Compound 1 undergoes electrochemically a partially reversible one-electron oxidation at $\mathrm{E}_{1 / 2}=$ $-0.133 \mathrm{~V}\left(v s . \mathrm{Fc}^{+} / \mathrm{Fc}\right)$ yielding a mixed-valent compound, $\left[\mathrm{Cu}_{3}{ }^{7+}\right]$ (vide infra), followed by an irreversible oxidation at $\sim 0 \mathrm{~V}$ (Figure 4). In contrast, a reduction to a $\left[\mathrm{Cu}_{3}{ }^{5+}\right]$ species is not accessible within the potential window $\left(+1.50 \mathrm{~V}\right.$ to $\left.-1.00 \mathrm{~V}, v s . \mathrm{Fc}^{+} / \mathrm{Fc}\right)$ of this study. Compound 3 is redox-inert, but becomes redox-active upon in situ addition of a base, which deprotonates the $\mu_{3}-\mathrm{OH}$ group, showing a reversible oxidation at $+0.004 \mathrm{~V}$. We have previously described the solution characterization of a series of $\left[\mathrm{Cu}_{3}\left(\mu_{3}-\mathrm{O}\right)(\mu-4-\mathrm{R}-\mathrm{pz})_{3} \mathrm{X}_{3}\right]^{\mathrm{z}}$ complexes and shown that substitution at the bridging pyrazole 4-position (R) and at the terminal ligand positions (X) influence the redox potential, revealing a trend that follows the order of electron withdrawing/releasing properties of the substituents. ${ }^{17}$ Compound $\mathbf{1}$ has the lowest oxidation potential (Table 1), an expected result given the position of the $O$-bound nitrite higher in the spectrochemical series. Chemical oxidation by a stoichiometric amount of benzoyl peroxide in 
$\mathrm{CH}_{2} \mathrm{Cl}_{2}$ results in formation of the formally $\mathrm{Cu}_{2}{ }_{2} \mathrm{Cu}^{\mathrm{III}}-$-compound, $\left\{\mathrm{MV}-\mathrm{Cu}_{3}\right\}$, accompanied by visible color change from greenish blue to reddish brown (Figure S8) with the appearance of new absorption band at $9191 \mathrm{~cm}^{-1}\left(9004 \mathrm{~cm}^{-1}\right.$ for 3, Figure S9) in the near-IR part of the electronic spectrum (Figure 5). The latter is tentatively assigned to an intervalence charge transfer (IVCT) band, characteristic of mixed-valent species. Computational analysis of the related chloroterminated compound $\left[\mathrm{Cu}_{3}\left(\mu_{3}-\mathrm{O}\right)(\mu-\mathrm{pz})_{3} \mathrm{Cl}_{3}\right]^{-}$has previously shown charge delocalization over metals and ligands in the HOMO with equal participation of all three $\mathrm{Cu}$-centers. ${ }^{18}$ Murray et al. have recently argued that such $\left[\mathrm{Cu}_{3} E\right]^{3+}$-mixed-valence systems should be called simply "covalent". 39 Analysis of this band by the Hush method results in a parameter $\Gamma=0.63$,

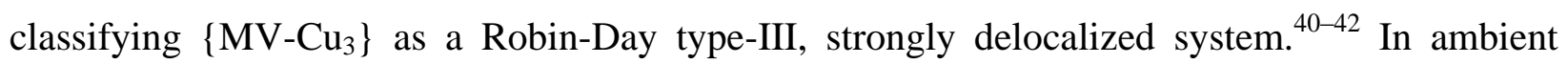
temperature solution, the IVCT bands collapse and the absorption spectra match those of compounds 1 and 3 (Figure S10); this is further confirmed by FT-IR spectra (Figure S11) and unit cell determination of the recrystallized reaction product. Free nitrite ions can be easily oxidized to nitrate by even mild oxidizing agents. However, here the coordinated nitrites of $\mathbf{1}$ and $\mathbf{3}$ are shielded from the oxidants by the easier metal-based oxidation.

Table 1. $\mathrm{E}_{1 / 2}$ values of the $\left[\mathrm{Cu}_{3}{ }^{7+} / \mathrm{Cu}_{3}{ }^{6+}\right]$ couple of $\left[\mathrm{Cu}_{3}\left(\mu_{3}-\mathrm{O}\right)(\mu-4-\mathrm{R}-\mathrm{pz})_{3} \mathrm{X}_{3}\right]^{\mathrm{z}} v s$. $\mathrm{Fc}^{+} / \mathrm{Fc}$.

\begin{tabular}{|l|l|l|l|}
\hline $\mathbf{R}$ & $\mathbf{X}$ & $\mathbf{E}_{1 / 2}(\mathbf{V})$ & Reference \\
\hline $\mathrm{H}$ & $\mathrm{ONO}$ & -0.133 & This work \\
\hline $\mathrm{H}$ & $\mathrm{Cl}$ & -0.013 & 18 \\
\hline $\mathrm{Ph}$ & $\mathrm{ONO}$ & +0.004 & This work \\
\hline $\mathrm{H}$ & $\mathrm{CF}_{3} \mathrm{CO}_{2}$ & +0.131 & 18 \\
\hline $\mathrm{H}$ & $\mathrm{NCS}$ & $+0.253\left(\mathrm{E}_{\mathrm{pa}}\right)^{*}$ & 17 \\
\hline $\mathrm{H}$ & py & +0.400 & 17 \\
\hline
\end{tabular}




\begin{tabular}{|l|l|l|l|}
\hline $\mathrm{H}$ & $\mathrm{CH}_{3} \mathrm{CO}_{2}$ & $+0.476\left(\mathrm{E}_{\mathrm{pa}}\right)^{*}$ & 17 \\
\hline $\mathrm{Cl}$ & $\mathrm{Cl}$ & +0.142 & 17 \\
\hline $\mathrm{Br}$ & $\mathrm{Cl}$ & +0.142 & 17 \\
\hline $\mathrm{CHO}$ & $\mathrm{Cl}$ & +0.280 & 17 \\
\hline $\mathrm{NO}_{2}$ & $\mathrm{Cl}$ & +0.449 & 17 \\
\hline
\end{tabular}

* Irreversible oxidations, only $\mathrm{E}_{\mathrm{pa}}$ values.

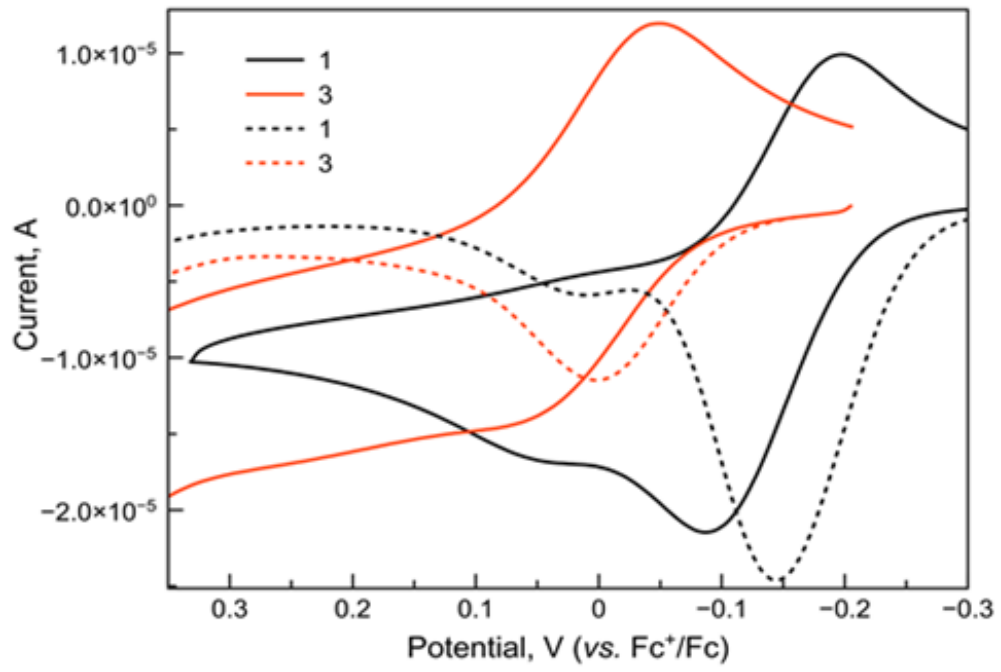

Figure 4. Cyclic voltammograms (solid lines) and differential pulse voltammograms (dashed lines) of compound $\mathbf{1}$ (black) and $\mathbf{3}$ (red) in $\mathrm{CH}_{2} \mathrm{Cl}_{2}$ with $\mathrm{TBAPF}_{6}$ as the supporting electrolyte. 


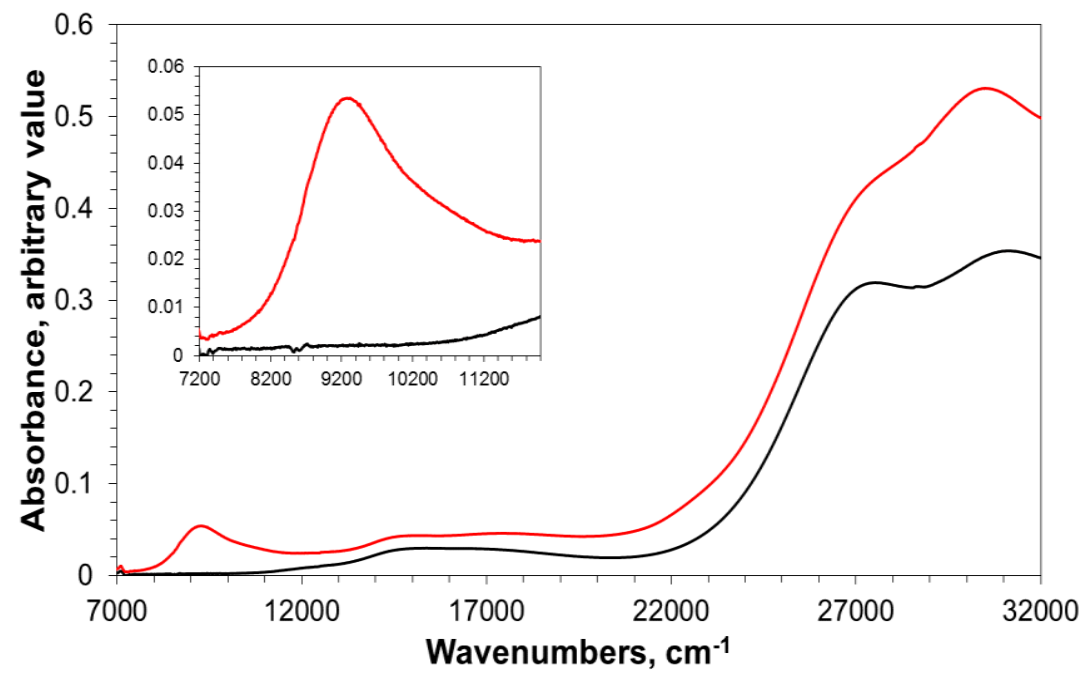

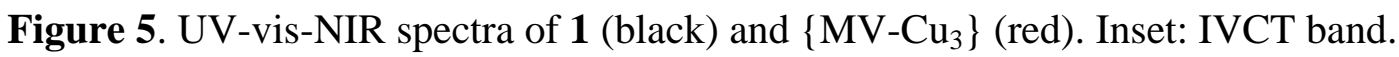

The +3 oxidation state of copper is not easily accessible and rarely encountered, in contrast to its more common +2 and +1 states. $\mathrm{Cu}^{\mathrm{III}}$-complexes have so far been isolated mostly with $\mathrm{F}$ and $\mathrm{CF}_{3}$ ligands, or under the protection of sterically restricting coordination environments. ${ }^{43-50}$ Some mononuclear $\mathrm{Cu}\left(\kappa^{2}-\mathrm{O}_{2}\right)$ complexes can be interpreted as $\mathrm{Cu}^{\mathrm{III}}-$ peroxides or $\mathrm{Cu}^{\mathrm{II}}$-superoxides. ${ }^{51}$ The involvement of $\mathrm{Cu}^{\mathrm{III}}$ species in $\mathrm{Cu}^{\mathrm{I}}$-catalyzed $\mathrm{C}$-C bond formation reactions (known since the turn of the $20^{\text {th }}$ century $)^{52}$ had been proposed, but only recently has it been demonstrated convincingly by studies employing rapid-injection NMR techniques. ${ }^{53}$ Various $\mathrm{Cu}^{\mathrm{III}}$-mediated and -catalyzed reactions have been reported. ${ }^{54-56}$ Crosscoupling reactions forming C-S, C-Se and C-P bonds, catalyzed by a $\mathrm{Cu}^{\mathrm{III}} / \mathrm{Cu}^{\mathrm{I}}-\mathrm{cycle}$ have been reported recently. ${ }^{57} \mathrm{~A} \mathrm{Cu}_{2}{ }_{2} \mathrm{Cu}^{\mathrm{III}}$-intermediate has been suggested as the catalytically-active species in the oxygenation of alkanes by oxygenases, such as particulate methane monooxygenase (pMMO). ${ }^{58,59}$ While the involvement of that oxidation state in enzymatic processes is disputed, ${ }^{60}$ synthetic $\mathrm{Cu}_{2}{ }_{2} \mathrm{Cu}^{\mathrm{III}}$ enzyme mimics have been suggested to carry out demanding chemical reactions, such as O-insertion into C-C and C-H bonds, ${ }^{58,61,62}$ including $\mathrm{CH}_{4}$ to $\mathrm{CH}_{3} \mathrm{OH}$ oxidation. ${ }^{63}$ 


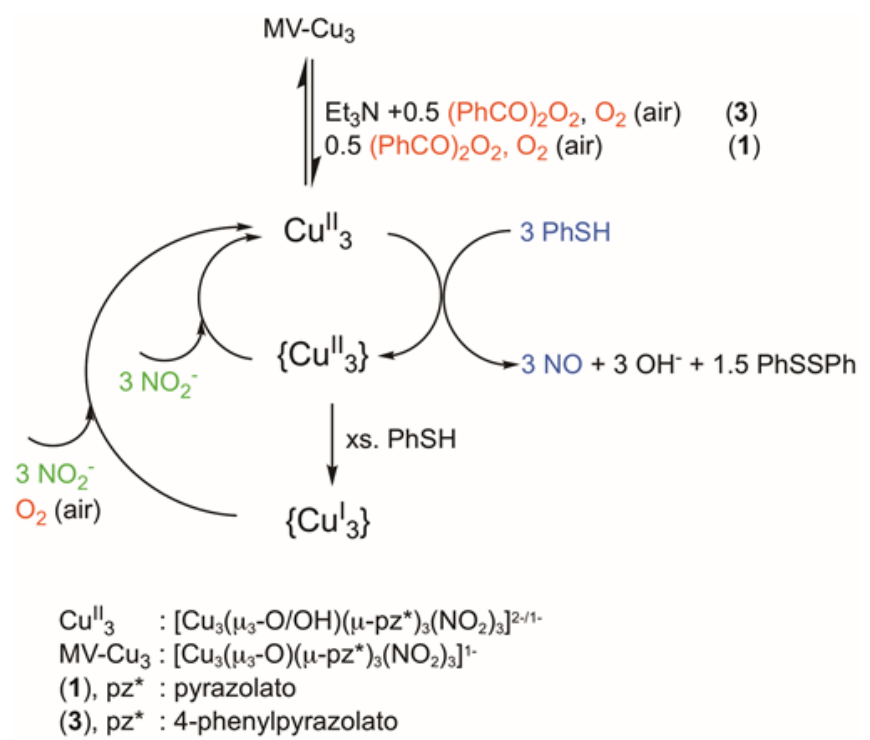

Scheme 2. Overall reactions investigated in the article. $\mathrm{Cu}_{3}{ }_{3}$ is compound $\mathbf{1}$ or $\mathbf{3}$; $\mathrm{pz}^{*}$ is pyrazolato (1) and 4-phenylpyrazolato $(\mathbf{3}) ;\left\{\mathrm{Cu}_{3}{ }_{3}\right\}$ is a transient species that has not been isolated; $\mathrm{MV}-\mathrm{Cu}_{3}$ is $\left[\mathrm{Cu}_{3}\left(\mu_{3}-\mathrm{O}\right)\left(\mu-\mathrm{pz}^{*}\right)_{3}(\mathrm{ONO})_{3}\right]^{1-}$.

\section{Ligand-based reduction of 1 and 3}

To examine the NO releasing capabilities of $\mathbf{1}$ and $\mathbf{3}, \mathrm{PhSH}$ was used as a proton and electron donor, while the $\mathrm{NO}$ gas released was trapped by tetraphenylporphyrinatocobalt(II) (CoTPP) in a closed two-vial system. The diagnostic shift of absorption maximum from $528 \mathrm{~nm}$ to $535 \mathrm{~nm}$ of the former indicated CoTPP(NO) formation (Figure $\mathrm{S} 3 \& \mathrm{~S} 4$ ). When the ratio of $\mathrm{Cu}_{3}{ }_{3}$ to $\mathrm{PhSH}$ is in the 1:1 to 1:3 range, NO release is triggered (Scheme 2 and Figures S3 and S4) leaving a green solution, presumed to be a solvent-stabilized $\mathrm{Cu}^{\mathrm{II}}$ species, $\left\{\mathrm{Cu}_{3}{ }_{3}\right\}$, which was not isolated. Reaction with additional $\mathrm{PhSH}$ caused the solution to become colorless, indicating reduction to a $\mathrm{Cu}(\mathrm{I})$ species, $\left\{\mathrm{Cu}_{3}^{\mathrm{I}}\right\}$. Addition of hexane to this reaction mixture caused precipitation of a pale yellow solid containing PhSSPh as determined by FT-IR (Figure S12). Upon addition of nitrite in a vessel open to the atmosphere, the colorless $\left\{\mathrm{Cu}_{3}^{\mathrm{I}}\right\}$ is readily cycled back to $\mathrm{Cu}_{3}^{\mathrm{II}}$, as confirmed by recrystallization and unit cell determination, with no NO production. However, when excess $\mathrm{NaNO}_{2}$ was present together with $\mathbf{1}$ or $\mathbf{3}$ in the reaction vessel, addition of $\mathrm{PhSH}$ in 
excess of the 1:3 ratio did not cause metal reduction, consuming $\mathrm{NaNO}_{2}$ and producing $\mathrm{NO}$ instead, indicating that the system is catalytic. Spectroscopic monitoring of the reaction of $\mathbf{1}$ or $\mathbf{3}$ with PhSH (Figure 6) shows the progressive formation of colorless $\left\{\mathrm{Cu}_{3}^{\mathrm{I}}\right\}$ and regeneration of $\mathbf{3}$ upon $\mathrm{NaNO}_{2}$ addition.

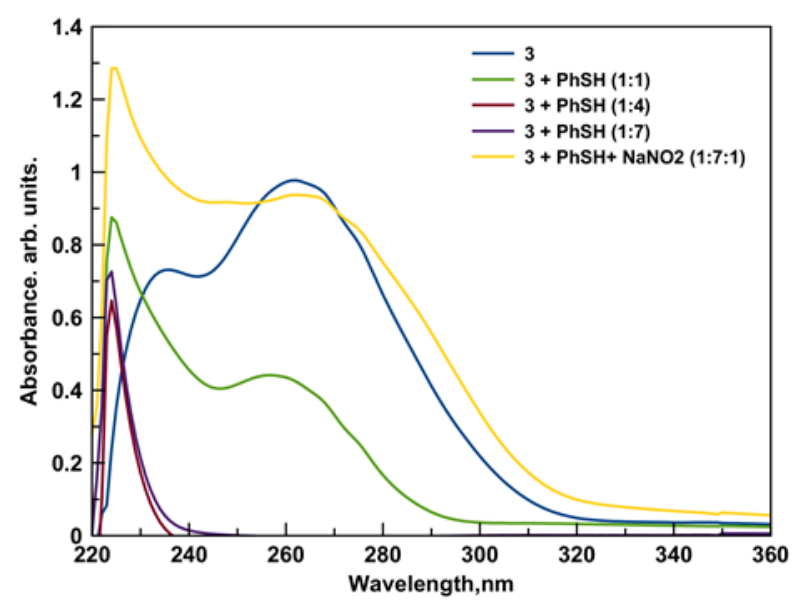

Figure 6. UV-vis spectroscopic monitoring of reaction of $\mathbf{3}$ upon stepwise addition of $\mathrm{PhSH}$ and $\mathrm{NaNO}_{2} / \mathrm{MeOH}$ in $\mathrm{CH}_{2} \mathrm{Cl}_{2}$.

Quantitative measurement of NO

The above qualitative observations have been confirmed by quantitative amperometric determination of NO release. An amperometric NO sensor was placed in a $5 \times 10^{-5} \mathrm{M}$ solution of 1 or 3 in $\mathrm{CH}_{2} \mathrm{Cl}_{2}$ and the response was recorded as $\mathrm{PhSH}$ was added. The $\mathrm{NO}$ yields measured with addition of a stoichiometric amount (three equivalents) of $\mathrm{PhSH}$ were $97 \%$ and $58 \%$ for 1 and $\mathbf{3}$, respectively. In order to evaluate the catalytic activity, the NO sensor was immersed initially in a solution of compound $\mathbf{1}$ (or 3 ) in $\mathrm{CH}_{2} \mathrm{Cl}_{2}$ and twenty equivalents of ethanolic $\mathrm{NaNO}_{2}$. Stepwise addition of twenty three equivalents of $\mathrm{PhSH}$ to the solution of $\mathbf{1}$ caused NO release, as follows: Almost quantitative NO release ( $97 \%)$ was observed up to the addition of the first thirteen $\mathrm{PhSH}$ equivalents, which decreased to $\sim 72 \%$ beyond that point, reaching the saturation point of the amperometric sensor. The corresponding measurements carried out with $\mathbf{3}$ 
showed only 57\% NO yield upon addition of a total of ten equivalents of $\mathrm{PhSH}$, accompanied by formation of a precipitate. The decrease of NO production over the course of the experiments is attributed to the accumulation of NO (pushing the reaction equilibrium backwards) and hydroxide in solution. Therefore, the turnover numbers (TON) of >14 (for 1) and >6 (for 3) are the lower limit values imposed by the experimental conditions.

Biological nitrite reduction by CuNIR proceeds at the type-II site by electrons derived from the oxidation of $\mathrm{Cu}^{\mathrm{I}}$ to $\mathrm{Cu}^{\mathrm{II}}$ at the type-I site:

$$
\mathrm{Cu}^{+}+\mathrm{NO}_{2}^{-}+2 \mathrm{H}^{+} \rightarrow \mathrm{Cu}^{2+}+\mathrm{NO}+\mathrm{H}_{2} \mathrm{O}
$$

In the present case, however, the source of electrons is the sacrificial $\mathrm{PhSH}$. Further experiments are required to determine whether reduction of nitrite takes place directly, or it is preceded by a metal-centered reduction to $\mathrm{Cu}^{\mathrm{I}}$-nitrite, followed by intramolecular redox rearrangement resulting in the observed products.

The results of this preliminary study show that the trinuclear $\mathrm{Cu}^{\mathrm{II}}$ species $\mathbf{1}$ and $\mathbf{3}$ mediate the following reaction:

$$
\mathrm{NO}_{2}^{-}+\mathrm{PhSH} \quad \rightarrow \quad \mathrm{NO}+\mathrm{OH}^{-}+1 / 2 \mathrm{PhSSPh}
$$

In a closed system, this reaction will proceed until the buildup of hydroxide either decomposes the catalyst to $\mathrm{Cu}(\mathrm{OH})_{2}$, or leads to formation of $\left[\mathrm{Cu}(\mu-\mathrm{OH})\left(\mu-\mathrm{pz}^{*}\right)\right]_{\mathrm{n}}$ species. $^{64}$ Blanks run without $\mathrm{PhSH}$, or without 1 (or 3), or with just 1 (or 3) and no proton donor, did not produce NO (Figure S5). During the NO sensing experiments with the amiNO-T meter, no NO response was seen until $\mathrm{PhSH}$ was added. 
In summary, we have described two trinuclear copper pyrazolato complexes that activate terminal $\kappa$-O-nitrito ligands towards reduction, with release of $\mathrm{NO}$, and stabilize them against oxidation to nitrates. The copper centers of complexes $\mathbf{1}$ and $\mathbf{3}$ differ from those encountered in CuNIR with regard to their coordination geometry: $\mathbf{1}$ and $\mathbf{3}$ contain $\mathrm{Cu}$-atoms with square planar trans $-\mathrm{N}_{2} \mathrm{O}_{2}$ coordination, while the mononuclear CuNIR are in a tetrahedral $\mathrm{N}_{3} \mathrm{O}$ environment. The X-ray structural data for $\mathbf{1}$ and $\mathbf{3}$ indicate that the $\kappa^{1}-\mathrm{O}$, but not the $\kappa^{2}-\mathrm{O}, \mathrm{O}$, coordination mode of nitrite results in activation of an $\mathrm{N}-\mathrm{O}$ bond. Addition of oxidizing agents to $\mathbf{1}$ or deprotonated 3 causes initially a copper-based oxidation to unstable mixed-valent $\left[\mathrm{Cu}_{3}\right]^{7+}$ species. In contrast, $\mathrm{PhSH}$, a reducing reagent capable of reducing both copper and nitrite, results in NO release. The NO releasing reaction is analogous to the well-known process of Snitrosothiols: $2 \mathrm{RSNO} \rightarrow \mathrm{RSSR}+2 \mathrm{NO}$. The catalytic release of NO by heterogeneous catalysts consisting of copper-based materials immobilized on solid supports have received attention recently, because of their potential therapeutic applications. ${ }^{65-67}$ To the best of our knowledge, compound $\mathbf{1}$ is the first homogeneous copper-catalyst and the first polynuclear-polynitrite NO releasing system reported to date; there is one example of an homogeneous iron-based catalyst. ${ }^{12}$

\section{Supporting Information}

Crystallographic and structure refinement data, UV-vis and luminescence spectra monitoring the NO release 1 and 3, infrared and ${ }^{1} \mathrm{H}-\mathrm{NMR}$ spectra. CCDC-1857948 to 1857950 contain the supplementary crystallographic data for this paper. These data can be obtained free of charge via www.ccdc.cam.ac.uk/conts/retrieving.html (or from the Cambridge Crystallographic Data 
Centre, 12 Union Road, Cambridge CB21EZ, UK; fax: (+44)1223-336-033; or deposit@ccdc.cam.ac.uk).

\section{Author Contributions}

The manuscript was written through contributions of all authors. All authors have given approval to the final version of the manuscript. "These authors contributed equally.

\section{ACKNOWLEDGMENT}

Work at FIU was supported by the National Science Foundation, USA (CHE-1213683 and CHE-1445803). This project has received funding (for AKB and PT) from the European Union's Horizon 2020 research and innovation programme under the Marie Sklodowska-Curie grant agreement No 746060 (project "CHIRALQUBIT"). We are grateful to Dr. Ziad Taha of Innovative Instruments, Inc., Sarasota, FL, for the loan of the NO-sensing equipment.

\section{AUTHOR INFORMATION}

\section{Corresponding Author}

*Raphael G. Raptis, rraptis@ fiu.edu

\section{Funding Sources}

National Science Foundation, USA (CHE-1213683 and CHE-1445803)

Horizon 2020 research and innovation programme under the Marie Sklodowska-Curie grant, European Union; agreement No 746060 (project “CHIRALQUBIT”). 


\section{REFERENCES}

(1) Maia, L. B.; Moura, J. J. G. How Biology Handles Nitrite. Chem. Rev. 2014, 114 (10), 5273-5357. https://doi.org/10.1021/cr400518y.

(2) Doane, T. A. The Abiotic Nitrogen Cycle. ACS Earth Space Chem. 2017, 1 (7), 411-421. https://doi.org/10.1021/acsearthspacechem.7b00059.

(3) Merkle, A. C.; Lehnert, N. Binding and Activation of Nitrite and Nitric Oxide by Copper Nitrite Reductase and Corresponding Model Complexes. Dalton Trans. 2012, 41 (12), 3355-3368. https://doi.org/10.1039/C1DT11049G.

(4) Cervantes, F. J.; De la Rosa, D. A.; Gómez, J. Nitrogen Removal from Wastewaters at Low C/N Ratios with Ammonium and Acetate as Electron Donors. Bioresour. Technol. 2001, 79 (2), 165-170. https://doi.org/10.1016/S0960-8524(01)00046-3.

(5) Blood, A. B.; Power, G. G. Nitrite: On the Journey from Toxin to Therapy. Clin. Pharmacokinet. 2015, 54 (3), 221-223. https://doi.org/10.1007/s40262-014-0231-5.

(6) Gomez Alvarez, E.; Amedro, D.; Afif, C.; Gligorovski, S.; Schoemaecker, C.; Fittschen, C.; Doussin, J.-F.; Wortham, H. Unexpectedly High Indoor Hydroxyl Radical Concentrations Associated with Nitrous Acid. Proc. Natl. Acad. Sci., USA 2013, 110 (33), 13294-13299. https://doi.org/10.1073/pnas.1308310110.

(7) Wasser, I. M.; de Vries, S.; Moënne-Loccoz, P.; Schröder, I.; Karlin, K. D. Nitric Oxide in Biological Denitrification: $\mathrm{Fe} / \mathrm{Cu}$ Metalloenzyme and Metal Complex NOx Redox Chemistry. Chem. Rev. 2002, 102 (4), 1201-1234. https://doi.org/10.1021/cr0006627.

(8) Timmons, A. J.; Symes, M. D. Converting between the Oxides of Nitrogen Using MetalLigand Coordination Complexes. Chem. Soc. Rev. 2015, 44 (19), 6708-6722. https://doi.org/10.1039/C5CS00269A.

(9) Peterson, R. L.; Kim, S.; Karlin, K. D. Copper Enzymes. In Comprehensive Inorganic Chemistry II; Elsevier, 2013; pp 149-177. https://doi.org/10.1016/B978-0-08-0977744.00309-0.

(10) Kundu, S.; Kim, W. Y.; Bertke, J. A.; Warren, T. H. Copper(II) Activation of Nitrite: Nitrosation of Nucleophiles and Generation of NO by Thiols. J. Am. Chem. Soc. 2017, 139 (3), 1045-1048. https://doi.org/10.1021/jacs.6b11332.

(11) Sakhaei, Z.; Kundu, S.; Donnelly, J. M.; Bertke, J. A.; Kim, W. Y.; Warren, T. H. Nitric Oxide Release via Oxygen Atom Transfer from Nitrite at Copper(II). Chem. Commun. 2017, 53 (3), 549-552. https://doi.org/10.1039/C6CC08745K.

(12) Sanders, B. C.; Hassan, S. M.; Harrop, T. C. $\mathrm{NO}_{2}{ }^{-}$Activation and Reduction to NO by a Nonheme $\mathrm{Fe}\left(\mathrm{NO}_{2}\right)_{2}$ Complex. J. Am. Chem. Soc. 2014, 136 (29), 10230-10233. https://doi.org/10.1021/ja505236x.

(13) Matson, E. M.; Park, Y. J.; Fout, A. R. Facile Nitrite Reduction in a Non-Heme Iron System: Formation of an Iron(III)-Oxo. J. Am. Chem. Soc. 2014, 136 (50), 17398-17401. https://doi.org/10.1021/ja510615p.

(14) Roger, I.; Wilson, C.; Senn, H. M.; Sproules, S.; Symes, M. D. An Investigation into the Unusual Linkage Isomerization and Nitrite Reduction Activity of a Novel Tris(2-Pyridyl) Copper Complex. Royal Soc. Open Sci. 2017, $4 \quad$ (8), 170593. https://doi.org/10.1098/rsos.170593.

(15) Woollard-Shore, J. G.; Holland, J. P.; Jones, M. W.; Dilworth, J. R. Nitrite Reduction by Copper Complexes. Dalton Trans. 2010, 39 (6), 1576-1585. https://doi.org/10.1039/B913463H. 
(16) Angaridis, P. A.; Baran, P.; Boča, R.; Cervantes-Lee, F.; Haase, W.; Mezei, G.; Raptis, R. G.; Werner, R. Synthesis and Structural Characterization of Trinuclear $\mathrm{Cu}^{\text {II }}$-Pyrazolato Complexes Containing $\mu_{3}-\mathrm{OH}, \mu_{3}-\mathrm{O}$, and $\mu 3-\mathrm{Cl}$ Ligands. Magnetic Susceptibility Study of $[\mathrm{PPN}]_{2}\left[\left(\mu_{3}-\mathrm{O}\right) \mathrm{Cu}_{3}(\mu-\mathrm{Pz})_{3} \mathrm{Cl}_{3}\right]$. Inorg. Chem. 2002, $41 \quad$ (8), 2219-2228. https://doi.org/10.1021/ic0106701.

(17) Rivera-Carrillo, M.; Chakraborty, I.; Mezei, G.; Webster, R. D.; Raptis, R. G. Tuning of the $\left[\mathrm{Cu}_{3}(\mu-\mathrm{O})\right]^{4+/ 5+}$ Redox Couple: Spectroscopic Evidence of Charge Delocalization in the Mixed-Valent $\left[\mathrm{Cu}_{3}(\mu-\mathrm{O})\right]^{5+}$ Species. Inorg. Chem. 2008, 47 (17), 7644-7650. https://doi.org/10.1021/ic800531y.

(18) Mezei, G.; McGrady, J. E.; Raptis, R. G. First Structural Characterization of a Delocalized, Mixed-Valent, Triangular $\mathrm{Cu}_{3}{ }^{7+}$ Species: Chemical and Electrochemical Oxidation of a $\mathrm{Cu}_{3}{ }_{3}\left(\mu_{3}-\mathrm{O}\right)$ Pyrazolate and Electronic Structure of the Oxidation Product. Inorg. Chem. 2005, 44 (21), 7271-7273. https://doi.org/10.1021/ic050729e.

(19) Hitchman, Michael A.; Rowbottom, Graham A. Transition Metal Nitrite Complexes. Coord. Chem. Rev. 1982, 42, 55-132.

(20) Atkins, P.; Overton, T.; Rourke, Jonathan; Weller, Mark; Armstrong, Fraser; Hagerman, Michael. Shriver and Atkins' Inorganic Chemistry, 5th ed.; OUP Oxford, 2010.

(21) Armarego, W. L. F.; Chai, C. Purification of Laboratory Chemicals; ButterworthHeinemann, 2013.

(22) APEX3; Bruker AXS Inc.: Madisson, WI, 2017.

(23) SADABS; Bruker AXS Inc.: Madisson, WI, 2001.

(24) Sheldrick, G. M. SHELXT - Integrated Space-Group and Crystal-Structure Determination. Acta Crystallogr. Sect. A. 2015, $71 \quad$ (1), 3-8. https://doi.org/10.1107/S2053273314026370.

(25) Dolomanov, O. V.; Bourhis, L. J.; Gildea, R. J.; Howard, J. a. K.; Puschmann, H. OLEX2: A Complete Structure Solution, Refinement and Analysis Program. J. Appl. Crystallogr. 2009, 42 (2), 339-341. https://doi.org/10.1107/S0021889808042726.

(26) Mathivathanan, L.; Cruz, R.; Raptis, R. G. A $\left[\mathrm{Cu}_{3}\left(\mu_{3}-\mathrm{O}\right)\right]-$ Pyrazolate Metallacycle with Terminal Nitrate Ligands Exhibiting Point Group Symmetry 3. Acta Crystallogr. Sect. E 2016, 72 (4), 492-494. https://doi.org/10.1107/S2056989016003741.

(27) Tocheva, E. I.; Rosell, F. I.; Mauk, A. G.; Murphy, M. E. P. Side-on Copper-Nitrosyl Coordination by Nitrite Reductase. Science 2004, 304 (5672), 867-870. https://doi.org/10.1126/science.1095109.

(28) Murphy, M. E. P.; Turley, S.; Adman, E. T. Structure of Nitrite Bound to CopperContaining Nitrite Reductase from Alcaligenes Faecalis: Mechanistic Implications. J. Biol. Chem. 1997, 272 (45), 28455-28460. https://doi.org/10.1074/jbc.272.45.28455.

(29) Antonyuk, S. V.; Strange, R. W.; Sawers, G.; Eady, R. R.; Hasnain, S. S. Atomic Resolution Structures of Resting-State, Substrate- and Product-Complexed Cu-Nitrite Reductase Provide Insight into Catalytic Mechanism. Proc. Natl. Acad. Sci., USA 2005, 102 (34), 12041-12046. https://doi.org/10.1073/pnas.0504207102.

(30) Mathivathanan, L.; Boudalis, A. K.; Turek, P.; Pissas, M.; Sanakis, Y.; Raptis, R. G. Interactions between H-Bonded $\left[\mathrm{Cu}_{3}{ }_{3}\left(\mu_{3}-\mathrm{OH}\right)\right]$ Triangles; a Combined Magnetic Susceptibility and EPR Study. Phys. Chem. Chem. Phys. 2018, 20 (25), 17234-17244. https://doi.org/10.1039/C8CP02643B.

(31) Mezei, G.; Rivera-Carrillo, M.; Raptis, R. G. Effect of Copper-Substitution on the Structure and Nuclearity of $\mathrm{Cu}(\mathrm{II})$-Pyrazolates: From Trinuclear to Tetra-, Hexa- and 
Polynuclear Complexes. Inorg. Chim. Acta 2004, 357 (12), 3721-3732. https://doi.org/10.1016/j.ica.2004.05.022.

(32) Pandolfo, L.; Pettinari, C. Trinuclear Copper(II) Pyrazolate Compounds: A Long Story of Serendipitous Discoveries and Rational Design. CrystEngComm. 2017, 19 (13), 17011720. https://doi.org/10.1039/C7CE00009J.

(33) Lehnert, N.; Cornelissen, U.; Neese, F.; Ono, T.; Noguchi, Y.; Okamoto, K.; Fujisawa, K. Synthesis and Spectroscopic Characterization of Copper(II)-Nitrito Complexes with Hydrotris(Pyrazolyl)Borate and Related Coligands. Inorg. Chem. 2007, 46 (10), 39163933. https://doi.org/10.1021/ic0619355.

(34) Boudalis, A. K.; Rogez, G.; Heinrich, B.; Raptis, R. G.; Turek, P. Towards Ionic Liquids with Tailored Magnetic Properties: Bmim ${ }^{+}$Salts of Ferro- and Antiferromagnetic $\mathrm{Cu}_{3}$ Triangles. Dalton Trans. 2017, $46 \quad$ (36), 12263-12273. https://doi.org/10.1039/C7DT02472J.

(35) Rakitin, Y.; Yablokov, Y.; Zelentsov, V. EPR Spectra of Trigonal Clusters. J. Magn. Reson. 1981, 43 (2), 288-301. https://doi.org/10.1016/0022-2364(81)90039-1.

(36) Tsukerblat, B. S.; Belinski, M. I.; Fainzilberg, V. E. Magnetochemistry and Spectroscopy of Transition Metal Exchange Clusters. Soviet Sci. Rev. B, Harwood Acad. Pub. 1987, 337-482.

(37) Sanakis, Y.; Macedo, A. L.; Moura, I.; Moura, J. J. G.; Papaefthymiou, V.; Münck, E. Evidence for Antisymmetric Exchange in Cuboidal [3Fe-4S $]^{+}$Clusters. J. Am. Chem. Soc. 2000, 122 (48), 11855-11863. https://doi.org/10.1021/ja002658i.

(38) Sanakis, Y.; Boudalis, A. K.; Tuchagues, J.-P. J-Strain and Antisymmetric Exchange in a Polynuclear Compound Containing the $\left\{\mathrm{Fe}_{3} \mathrm{O}\right\}^{7+}$ Core. Compt. Rend. Chim. 2007, 10 (12), 116-124. https://doi.org/10.1016/j.crci.2006.09.008.

(39) Cook, B. J.; Di Francesco, G. N.; Ferreira, R. B.; Lukens, J. T.; Silberstein, K. E.; Keegan, B. C.; Catalano, V. J.; Lancaster, K. M.; Shearer, J.; Murray, L. J. Chalcogen Impact on Covalency within Molecular $\left[\mathrm{Cu}_{3}\left(\mu_{3}-\mathrm{E}\right)\right]^{3+}$ Clusters $(\mathrm{E}=\mathrm{O}, \mathrm{S}, \mathrm{Se})$ : A Synthetic, Spectroscopic, and Computational Study. Inorg. Chem. 2018, 57 (18), 11382-11392. https://doi.org/10.1021/acs.inorgchem.8b01000.

(40) Concepcion, J. J.; Dattelbaum, D. M.; Meyer, T. J.; Rocha, R. C. Probing the Localizedto-Delocalized Transition. Philos. Trans. R. Soc. A 2008, 366 (1862), 163-175. https://doi.org/10.1098/rsta.2007.2148.

(41) Robin, M. B.; Day, P. Mixed Valence Chemistry-A Survey and Classification. In $A d v$. Inorg. Chem. Radiochem. Elsevier, 1968, 10, 247-422. https://doi.org/10.1016/S00652792(08)60179-X.

(42) Allen, G. C.; Hush, N. S. Intervalence-Transfer Absorption. Part 1. Qualitative Evidence for Intervalence-Transfer Absorption in Inorganic Systems in Solution and in the Solid State. In Progress in Inorganic Chemistry; Cotton, F. A., Ed.; John Wiley \& Sons, Inc.: Hoboken, NJ, USA, 1967; pp 357-389. https://doi.org/10.1002/9780470166093.ch6.

(43) Willert-Porada, M. A.; Burton, D. J.; Baenziger, N. C. Synthesis and X-Ray Structure of Bis(Trifluoromethyl)(N,N-Diethyldithiocarbamato)-Copper; a Remarkably Stable Perfluoroalkylcopper(III) Complex. J. Chem. Soc., Chem. Commun. 1989, o (21), 16331634. https://doi.org/10.1039/C39890001633.

(44) Romine, A. M.; Nebra, N.; Konovalov, A. I.; Martin, E.; Benet-Buchholz, J.; Grushin, V. V. Easy Access to the Copper(III) Anion $\left[\mathrm{Cu}\left(\mathrm{CF}_{3}\right)_{4}\right]^{-}$. Angew. Chem. Int. Ed. 2015, 54 (9), 2745-2749. https://doi.org/10.1002/anie.201411348. 
(45) Santo, R.; Miyamoto, R.; Tanaka, R.; Nishioka, T.; Sato, K.; Toyota, K.; Obata, M.; Yano, S.; Kinoshita, I.; Ichimura, A.; et al. Diamagnetic-Paramagnetic Conversion of Tris(2Pyridylthio)Methylcopper(III) through a Structural Change from Trigonal Bipyramidal to Octahedral. Angew. Chem. Int. Ed. 2006, 45 (45), 7611-7614. https://doi.org/10.1002/anie.200603127.

(46) Ribas, X.; Jackson, D. A.; Donnadieu, B.; Mahía, J.; Parella, T.; Xifra, R.; Hedman, B.; Hodgson, K. O.; Llobet, A.; Stack, T. D. P. Aryl C-H Activation by $\mathrm{Cu}^{\mathrm{II}}$ To Form an Organometallic Aryl-Cu ${ }^{\text {III }}$ Species: A Novel Twist on Copper Disproportionation. Angew. Chem. Int. Ed. 2002, 41 (16), 2991-2994.

(47) Furuta, H.; Maeda, H.; Osuka, A. Doubly N-Confused Porphyrin: A New Complexing Agent Capable of Stabilizing Higher Oxidation States. J. Am. Chem. Soc. 2000, 122 (5), 803-807. https://doi.org/10.1021/ja992679g.

(48) Dhar, D.; Yee, G. M.; Tolman, W. B. Effects of Charged Ligand Substituents on the Properties of the Formally Copper(III)-Hydroxide $\left([\mathrm{CuOH}]^{2+}\right)$ Unit. Inorg. Chem. 2018, 57 (16), 9794-9806. https://doi.org/10.1021/acs.inorgchem.8b01529.

(49) Neisen, B. D.; Gagnon, N. L.; Dhar, D.; Spaeth, A. D.; Tolman, W. B. Formally Copper(III)-Alkylperoxo Complexes as Models of Possible Intermediates in Monooxygenase Enzymes. J. Am. Chem. Soc. 2017, 139 (30), 10220-10223. https://doi.org/10.1021/jacs.7b05754.

(50) Spaeth, A. D.; Gagnon, N. L.; Dhar, D.; Yee, G. M.; Tolman, W. B. Determination of the $\mathrm{Cu}(\mathrm{III})-\mathrm{OH}$ Bond Distance by Resonance Raman Spectroscopy Using a Normalized Version of Badger's Rule. J. Am. Chem. Soc. 2017, 139 (12), 4477-4485. https://doi.org/10.1021/jacs.7b00210.

(51) Mirica, L. M.; Ottenwaelder, X.; Stack, T. D. P. Structure and Spectroscopy of Copper-Dioxygen Complexes. Chem. Rev. 2004, 104 (2), 1013-1046. https://doi.org/10.1021/cr020632z.

(52) Fischer, C.; Koenig, B. Palladium- and Copper-Mediated N-Aryl Bond Formation Reactions for the Synthesis of Biological Active Compounds. Beilstein J. Org. Chem. 2011, 7 (1), 59-74. https://doi.org/10.3762/bjoc.7.10.

(53) Bertz, S. H.; Cope, S.; Murphy, M.; Ogle, C. A.; Taylor, B. J. Rapid Injection NMR in Mechanistic Organocopper Chemistry. Preparation of the Elusive Copper(III) Intermediate. J. Am. Chem. Soc. 2007, 129 (23), 7208-7209. https://doi.org/10.1021/ja067533d.

(54) van Koten, G. Organocopper Compounds: From Elusive to Isolable Species, from Early Supramolecular Chemistry with RCuI Building Blocks to Mononuclear $\mathrm{R}_{2-n} \mathrm{Cu}^{\mathrm{II}}$ and $\mathrm{R}_{3-}$ ${ }_{\mathrm{m}} \mathrm{Cu}^{\mathrm{III}}$ Compounds. A Personal View. Organometallics 2012, 31 (22), 7634-7646. https://doi.org/10.1021/om300830n.

(55) Casitas, A.; Ribas, X. The Role of Organometallic Copper(III) Complexes in Homogeneous Catalysis. Chem. Sci. 2013, 4 (6), 2301-2318. https://doi.org/10.1039/C3SC21818J.

(56) Hickman, A. J.; Sanford, M. S. High-Valent Organometallic Copper and Palladium in Catalysis. Nature. 2012, 484 (7393), 177. https://doi.org/10.1038/nature11008.

(57) Font, M.; Parella, T.; Costas, M.; Ribas, X. Catalytic C-S, C-Se, and C-P Cross-Coupling Reactions Mediated by a $\mathrm{Cu}^{\mathrm{I}} / \mathrm{Cu}^{\mathrm{III}}$ Redox Cycle. Organometallics 2012, 31 (22), 79767982. https://doi.org/10.1021/om3006323. 
(58) Chen, P. P.-Y.; Nagababu, P.; Yu, S. S.-F.; Chan, S. I. Development of the Tricopper Cluster as a Catalyst for the Efficient Conversion of Methane into MeOH. ChemCatChem. 2014, 6 (2), 429-437. https://doi.org/10.1002/cctc.201300473.

(59) Shiota, Y.; Juhász, G.; Yoshizawa, K. Role of Tyrosine Residue in Methane Activation at the Dicopper Site of Particulate Methane Monooxygenase: A Density Functional Theory Study. Inorg. Chem. 2013, 52 (14), 7907-7917. https://doi.org/10.1021/ic400417d.

(60) Balasubramanian, R.; Smith, S. M.; Rawat, S.; Yatsunyk, L. A.; Stemmler, T. L.; Rosenzweig, A. C. Oxidation of Methane by a Biological Dicopper Centre. Nature. 2010, 465 (7294), 115-119. https://doi.org/10.1038/nature08992.

(61) Chen, P. P.-Y.; Yang, R. B.-G.; Lee, J. C.-M.; Chan, S. I. Facile O-Atom Insertion into C $\mathrm{C}$ and $\mathrm{C} \mathrm{H}$ Bonds by a Trinuclear Copper Complex Designed to Harness a Singlet Oxene. Proc. Natl. Acad. Sci., USA 2007, 104 (37), 14570-14575. https://doi.org/10.1073/pnas. 0707119104.

(62) Lionetti, D.; Day, M. W.; Agapie, T. Metal-Templated Ligand Architectures for Trinuclear Chemistry: Tricopper Complexes and Their $\mathrm{O}_{2}$ Reactivity. Chem. Sci. 2013, 4 (2), 785-790. https://doi.org/10.1039/C2SC21758A.

(63) Chan, S. I.; Lu, Y.-J.; Nagababu, P.; Maji, S.; Hung, M.-C.; Lee, M. M.; Hsu, I.-J.; Minh, P. D.; Lai, J. C.-H.; Ng, K. Y.; et al. Efficient Oxidation of Methane to Methanol by Dioxygen Mediated by Tricopper Clusters. Angew. Chem. Int. Ed. 2013, 52 (13), 37313735. https://doi.org/10.1002/anie.201209846.

(64) Ahmed, B. M.; Mezei, G. From Ordinary to Extraordinary: Insights into the Formation Mechanism and PH-Dependent Assembly/Disassembly of Nanojars. Inorg. Chem. 2016, 55 (15), 7717-7728. https://doi.org/10.1021/acs.inorgchem.6b01172.

(65) Wonoputri, V.; Gunawan, C.; Liu, S.; Barraud, N.; Yee, L. H.; Lim, M.; Amal, R. Copper Complex in Poly(Vinyl Chloride) as a Nitric Oxide-Generating Catalyst for the Control of Nitrifying Bacterial Biofilms. ACS Appl. Mater. Interfaces. 2015, 7 (40), 22148-22156. https://doi.org/10.1021/acsami.5b07971.

(66) Yang, Z.; Yang, Y.; Xiong, K.; Wang, J.; Lee, H.; Huang, N. Metal-Phenolic Surfaces for Generating Therapeutic Nitric Oxide Gas. Chem. Mater. 2018. 30(15), 5220-5226. https://doi.org/10.1021/acs.chemmater.8b01876.

(67) Paolucci, C.; Khurana, I.; Parekh, A. A.; Li, S.; Shih, A. J.; Li, H.; Iorio, J. R. D.; Albarracin-Caballero, J. D.; Yezerets, A.; Miller, J. T.; et al. Dynamic Multinuclear Sites Formed by Mobilized Copper Ions in $\mathrm{NO}_{\mathrm{x}}$ Selective Catalytic Reduction. Science. 2017, 357 (6354), 898-903. https://doi.org/10.1126/science.aan5630. 


\section{Synopsis}

A tricopper(II) NO-releasing homogeneous catalyst: Terminal $\kappa^{1}-\mathrm{O}$ and $\kappa^{2}-\mathrm{O}, \mathrm{O}$ coordination of nitrites to a triangular $\mathrm{Cu}_{3}{ }_{3}\left(\mu_{3}-\mathrm{O} / \mathrm{OH}\right)$-pyrazolato scaffold shields them against oxidation and activates their homogeneous catalytic reduction with NO release.

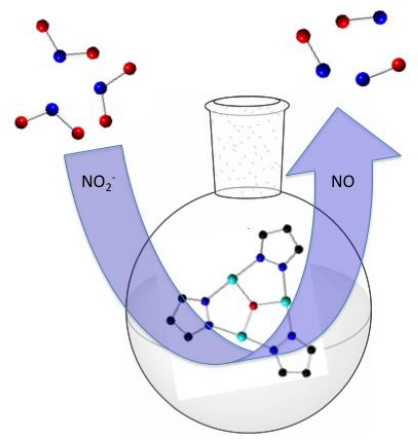

